УДК 339.92:332.1

\title{
Sergei KOVALENKO
}

PhD in Economics, Associate Professor, Department of Humanitarian Sciences, Danube Institute of National University «Odessa Maritime Academy», e-mail: econ69@mail.ru

\section{THE CROSS-BORDER MESO-LEVEL OF CLUSTER FORMS DEVELOPMENT OF INDUSTRIAL INTEGRATION}

Kovalenko, S. (2017). The cross-border meso-level of cluster forms development of industrial integration. Ed.: M. Zveryakov (ed.-in-ch.) and others [Transkordonnyi mezoriven rozvytku klasternykh form promyslovoi intehratsii; za red.: M. I. Zveriakova (gol. red.) ta in.], Socio-economic research bulletin; Visnik social'no-ekonomičnih doslidžen' (ISSN 2313-4569), Odessa National Economic University, Odessa, No. 2-3 (63-64), pp. 37-49.

\begin{abstract}
The article examines the main features inherent to meso-level of international integration formations representing network structures in intra-branch and inter-branch cooperation in the form of cross-border cluster systems encompassing macro-level and micro-level of integration of national economies. Possibilities of theory synthesis of international economic integration and cluster concept in economic area virtualization environment are revealed. Cluster approach is proved to be the most efficient mechanism to develop cross-border economic relations and represents, finally, a meso-level of competitive international integration systems and mandatory condition of quality advance for Ukrainian European integration. The essence and inner interrelations of cross-border network cluster are investigated as the growth factor of the European region competitiveness under the conditions of intensifying the integration processes and the necessity of enhancement of the role of periphery regions' economy in the framework of cross-border cooperation. Within the context of European Union regional politics the strategic priorities of the spatial development of the European regions are stated on the basis of self-organization of "hybrid" network quasi integration institutions. Their role in the competitive recovery of the European regions in the light of Ukrainian perspectives of joining European Union is investigated.
\end{abstract}

Keywords: cross-border cluster system; meso-level; meso-economic synthesis; European integration; European region; innovations; competitiveness.

\section{Сергій Іванович КОВАЛЕНКО}

кандидат економічних наук, дочент кафедри гуманітарних дисииплін, Дунайський інститут Національного університету «Одеська морська академія», e-mail:econ69@mail.ru

\section{ТРАНСКОРДОННИЙ МЕЗОРІВЕНЬ РОЗВИТКУ КЛАСТЕРНИХ ФОРМ ПРОМИСЛОВОЇ ІНТЕГРАЦЇ̈}

Коваленко, С. І. Транскордонний мезорівень розвитку кластерних форм промислової інтеграиії // Вісник сочіально-економічних досліджень: зб. наук. праць; за ред. М. I. Звєрякова (голов. ред.) та ін. (ISSN 2313-4569). Одеса: Одеський національний економічний університет. - 2017. - № 2-3 (63-64). - С. 37-49.

\begin{abstract}
Анотація. У статті досліджено основні характеристики мезорівня міжнародних інтеграційних об'єднань, щзо $\epsilon$ мережевими структурами внутрішньогалузевого ц̆ міжгалузевого співробітництва у вигляді транскордонних кластерних систем, які об'єднують макро- і мікрорівень інтеграчій національних економік. Виявлено можливості синтезу теорії міжнародної економічної інтеграції $i$ кластерної концепції в умовах віртуалізації економічного простору. Обгрунтовано, щуо кластерний підхід є найбільш ефективним механізмом розвитку транскордонних економічних взаємодій $i$, зрештою, $\epsilon$ мезорівнем конкурентоспроможних міжнародних інтеграційних систем і необхідною умовою якісного росту євроінтегращії Украӥни. Досліджено сутність і внутрішні взаємозв'язки транскордонного мережевого кластера як чинника зростання конкурентоспроможності єврорегіону в умовах посилення інтеграчійних процесів $і$ необхідності підвищення ролі економіки периферійних регіонів у рамках транскордонного співробітництва. У контексті регіональної політики Євросоюзу визначено стратегічні пріоритети просторового розвитку єврорегіонів на підставі самоорганізації «гібридних» інститутів мережевої квазіінтеграџіï, розглянуто їх роль у підвищенні конкурентоспроможності єврорегіонів у світлі перспектив вступу України до ЄС.
\end{abstract}

Ключові слова: транскордонна кластерна система; мезорівень; мезоекономічний синтез; євроінтегращія; єврорегіон; інновачії; конкурентоспроможність. 


\title{
Сергей Иванович КОВАЛЕНКО
}

кандидат экономических наук, дочент кафедры гуманитарных дисциплин, Дунайский институт Наџионального университета «Одесская морская академия», e-mail:econ69@mail.ru

\section{ТРАНСГРАНИЧНЫЙ МЕЗОУРОВЕНЬ РАЗВИТИЯ КЛАСТЕРНЫХ ФОРМ ПРОМЫШЛЕННОЙ ИНТЕГРАЦИИ}

\begin{abstract}
Коваленко, С. И. Трансграничный мезоуровень развития кластерных форм промышленной интеграции // Вестник соииально-экономических исследований: сб. науч. трудов под ред. М. И. Зверякова (әлав. ред.) и др. (ISSN 2313-4569). - Одесса: Одесский национальный экономический университет. - 2017. - № 2-3 (63-64). C. 37-49.
\end{abstract}

\begin{abstract}
Аннотация. В статье исследованы основные характеристики мезоуровня международных интеграционных объединений, представляющего собой сетевые структуры внутриотраслевого и межотраслевого сотрудничества в виде трансграничных кластерных систем, объединяющих макро- и микроуровень интеграции нациинальных экономик. Выявлены возможности синтеза теории международной экономической интеграции и кластерной концепциии в условиях виртуализации экономического пространства. Обосновано, что кластерный подход является наиболее эффективным механизмом развития трансграничных экономических взаимодействий $и$, в конечном итоге, представляет собой мезоуровень конкурентоспособных международных интеграционных систем и необходимое условие качественного роста евроинтеграции Украины. Исследованы сущуность и внутренние взаимосвязи трансграничного сетевого кластера как фактора роста конкурентоспособности еврорегиона в условиях усиления интеграционных процессов и необходимости повышения роли экономики периферийных регионов в рамках трансграничного сотрудничества. В контексте региональной политики Евросоюза определены стратегические приоритеть пространственного развития еврорегионов на основе самоорганизации «гибридных» институтов сетевой квазиинтеграции, рассмотрена их роль в повышении конкурентоспособности еврорегионов в свете перспектив вступления Украины в ЕС.
\end{abstract}

Ключевье слова: трансграничная кластерная система; мезоуровень; мезоэкономический синтез; евроинтеграция; еврорегион; инновации; конкурентоспособность.

JEL classification: C120; C140; C180

\section{Introduction}

Cross-border cooperation becomes the key factor of European integration enhancement under those circumstances when in political and scientific discourse the concept "boundary" is perceived not as "boundary line", but is transformed into "relationship factor" being understood "not as a line, but a functional space", where "various communities and groups" interact.

Active formation of network forms of cross-border economic area self-organization corresponds to the impulse of establishing of the new economic reality of postmodernity that denies "total ideology", but accepts the variety and freedom of economic choice. Network clusters become a new source of competitive advantages of the European regions involving Ukraine and change not only the local factors system, but also the structure of economic area itself. In large measure the implementation of cluster form of business organization in cross-border dimension makes it possible to develop the network structure of economic area, to enhance its unity and entity [1, p.4].

Nowadays the most efficient direction of innovative policy is the formation and development of cross-border clusters which become more popular in the world society on the international, national and regional levels. Usage of cluster approach is an effective way of competitive recovery of the small and medium business in regional economy. In this respect the task of formation of united innovative infrastructure, providing effective use of scientific and technological potential of crossborder regions, creating the conditions for modernization of the industry and the acceleration of development of its most successful and competitive segment, becomes the most significant one. The necessity of development and realization of scientifically grounded regional economic 
policy concerning border regions and territories of Ukraine is evident within the framework of the processes of international economic integrity. As the experience of the countries involved in the processes of international integrity shows, under such conditions the status and role of the border regions in the development of national economy are sufficiently changed. The latter lose their "periphery" status and their "barrier" functions, being not only the transit corridor for innovations, goods and services, but also regional "poles" of integrity and interplay of global and national economic areas.

The unified concept of European economic integration is not yet formed taking into account development methodology for international industrial and innovative clusters. This problem statement may be described as a meso-economical synthesis of development strategies of international manufacturing and innovative clusters and international integration formations and, to the author's opinion, it enables to draw up both practical mechanism as well, as scientific idea of development for modern integration systems.

The relevance of our investigation on one hand is determined by the important role of cross-border cooperation to enhance the competitiveness of periphery border regions, to decrease spatial differentiation between border and internal sub-regions and on the other, by not adequate investigation of theoretical and methodological aspects of the study of the mechanisms of crossborder cooperation. To make the cooperation more effective, to cancel the negative influence of the borders and to achieve full scale integral area, the modern regional policy of European Union motivated the search of new forms of cross-border cooperation [2, p.10].

\section{Analysis of research and publications of recent years}

Review of researches and publications for the latest years shows great interest in the competitiveness problems existing in regions adjacent to states' borders. Possibilities to apply marketing tools for clusterization processes are studies in works by M. Porter, H. G. Bolt, I. Tolenado, P. Doyle, F. Kottler, H. Lyce, J.-J. Lambain, E. Toffler and many others. As experience shown in advanced states development worldwide confirms, economic competitiveness may be only achieved by means of applying innovative development model with final aim of implementation to increase well-being of nation by means of acceleration in economic growth.

Problems in market structural modernization and competitive development as factors stimulating innovative activeness of economic systems are reviewed in researching works by J. Schumpeter, K. Arrow, R. Nelson and S. Winter. The enlisted scientists researched market subjects' integration mechanism, formation of innovations structures to generate manufacturing, technological and organizational advance. Representatives of the institutionalism O. Williamson [3], R. Coase [4], W. Nordhaus, F. Hayek contributed greatly to solve the problem on the question. The enlisted persons in their works applied efforts in the areas, as follows:

1) pointed out drawbacks in information preventing mutually beneficial activities, discrepancies between apparent and hidden knowledge;

2) concentrated on studying influence of transaction expenditures upon advantages of various forms of organization. Modern sources classify industrial areas, holdings, clusters, territorial manufacturing complexes as territorial forms of network industrial integration, encompassing regions, technological platforms, etc. [4]. As time ran the concept of "industrial area" evolved - analysis of notable characteristics was made by A. Marshall, G. Becattini, O. Williamson [5, p.211].

Nowadays there are various hybrid forms in cross-border quasi-integration involving euroregional subjects of economy with stable long-term contacts and assigned control of common activities due to lack of legally supported proprietary titles transfer, such as clusters, business associations, strategic alliances, various network formations [6]. 
Michael Porter in his work "Competitive Advantage of Nations" draws a remarkable conclusion, as follows, "...developing an investment policy transition economy should strive to develop mutually dependent industrial cluster involving basic and auxiliary branches of industry" [7]. Approach to estimate a regional competitiveness may be formulated basing upon a national competititveness concept proposed by M. Porter.

\section{Problem description}

Model "Expenditures - Production" was applied to review inter-branch cooperation within a cluster and tools selection to identify and evaluate cluster' development level as well, as works by national scientists, such as M. P. Voynarenko, V. I. Zakharchenko, N. A. Mykula and foreign researchers, such as U. Aisard, V. Leontyev, P. Neikampf. Ukrainian research materials and publications dealing with problems of cross-border industrial clustering are insufficient so far. Furthermore, there is an obvious falling behind time of scientific evaluation and practical steps of development, which are already being implemented both by business and adjacent states for clustering regional economic space. Yet, needed theoretical foundation enabling to adapt the Porter's cluster concept for national specifics was represented by explorations of problems of cross-border regional competition carried on in Institute of Market Problems and Economical and Ecological Researches of Ukrainian National academy of Sciences. Still the problem remains unsolved as regards filling the gap between industrial cluster model theoretical construction and requirements of business and public entities to scientific grounding of adopted strategic decisions on the meso-level [8, p.33]. It means still existing necessity in development of methodological tools of model application in developing trends and measures in cross-border industrial policy, development strategies and programs for the Black Sea euroregions, corporative competition strategies. Furthermore, cluster theory is being linked with corporative theory, theory of innovative development, theory of economic progress. However, with all the available substantial researches in network clusters, these structures in cross-border aspects remain insufficiently studied both in the terminology and sensual areas.

The work has as its aim providing a scientific grounding for synthesis of cross-border cluster systems as a meso-level of international integration formations, which become poles for euroregional economic progress and finding an opportunity to implement this concept in the process of European integration for Ukraine.

\section{The main material research}

Modern industrial and innovations clusters take a form of international (cross-border) cluster systems, which may be regarded as a major research object for mesoeconomics, i. e. the crucial meso-economic system. Mesoeconomics should be intended to play a part of linking bridge between microeconomics and macroeconomics but it is an under-estimated component of economic science, especially in view of modern international economic relations. In brief, meso-economics may be defined as a system of interconnections between branches of economy consisting of networks and chains of certain types.

Meso-level of international economic integration is an organization structure of intra-industry and inter-industrial cooperation in a form of international cluster systems which integrate micro- and macro-levels of integration of national economies. Cross-border economic interactions should be highlighted as a component of meso-economy leading to cross-border regions formations (contact function performance) [9, p.18].

National clusters, as their development advanced, became to expand beyond national borders in areas adjacent to national borders. In other words, the cluster paradigm shifted into a sphere of cross-border and international cooperation with the concept of cluster cooperation becoming a matter of several states instead of single. At the same time process of virtualization of intercorporation cooperation and, respectively, clusters' virtualization started gradually. 
In general, international clusters system concept synthesis logics as a meso-level of international economic integrations bases on the criteria, as below:

- demand to increase efficiency of regional integration formations with accelerating economic and innovative cycles;

- development of meso-level of international economic integration (regions, institutions, intercorporations network);

- international cluster systems which display most completely meso-economic approach in modern conditions;

- international clusters as business and ecologic systems, evolutional, network approach to development of international economic integration.

Cross-border cluster systems are advantageous since they generate certain synergy effects and increase efficiency being of low cost at the same time. Main synergy sources in clusters are knowledge exchange, accessible pools of skilled competent employees for participants in cluster or accessible general public benefits. Cluster in this context represent signal characteristics of "real" economics.

Cluster thinking and cluster strategies possess a potential to speed up regional economic progress and facilitate to economic restructuring. However, the most important factor in this context consists in clusters being a paradigm to a greater extent. So, the second reason to turn to cluster concept consists in capability of clusters, further to a mere practical aspect, to provide a powerful paradigm to understand principles of economic life and economic policy.

And, finally, from the economic policy point of view, the third reason of modern turning to clusters consists in the clusters' capability to construct pre-manufacturing postmodern economic system and to evade rhetoric of obsolete "industrial policy" enabling, nevertheless, national authorities to strengthen national competitiveness.

Cross-border clusters form in regions adjacent to borders of two, or more States "over and beyond" their administrative borders. They encompass adjacent territories with institutions and corporations residing at either side of a border, or even at both sides. The cross-border clusters therefore may be defined as groups of independent companies which are geographically located in cross-border region; cooperate and compete; are specialized in different branches, connected with common technologies and skills and complement each other, all of which in total enables to obtain synergy and networked effects, knowledge and skills diffusion.

The cross-border cluster systems (CBCS) are proposed for consideration as strategic planning objects meaning territorially localized social and economic systems formed by a group of independent economic subjects at both sides of national border involving organization of public authorities of States representing both euroregion and civil society, cooperate steadily with each other by means of data exchange, services exchange, personnel exchange and funds exchange and achieve higher efficiency in comparison with other objects being not organized systematically. The CBCS may become centers of regional development by means of attracting investors, implementing and spreading innovations, forming personnel fund of newer quality, business culture, adequate institutions development aiming to solve problems of national economy modernization in general.

The CBCS is considered as a network structure involving interconnected territorially and complementary enterprises located at either side of national border (including specialized suppliers of raw materials, components and services as well as manufacturers and customers) grouped around scientific and innovation centre with vertical links with local authorities to improve competitiveness of enterprises, regions and national economy. The "Cross-border Cluster" term displays the fact that corporations in the global instability conditions compete with each other not so much in 
productivity than in the capability to innovations. The cluster unions of enterprises are capable to adapt to modern innovation processes. Cluster strategy of cross-border cooperation provides formation or territorially localized cluster units of regions adjacent to national borders around foreign innovation corporations whose network agents (manufacturers of innovative production and service providers, suppliers, infrastructure objects, scientific and research centers, higher education establishments) cooperate basing on principles of competition and cooperation and generating synergy effect, complementing each other and increasing competitive advantages of both individual corporations and the cluster in general.

Classic integration provides total control establishment both in respect of property and assets of united business entities. Depending on scope of activity a number of integration kinds may be classified. Horizontal integration consolidates manufacturers being at the same chain stage and provides advantage due to scale effect. Vertical integration represents a strategy protecting essential business from markets' deficiencies. Reverse vertical integration (at the initial stage of manufacturing chain) is normally necessary to protect from suppliers' monopoly. Direct integration enables to increase added value and influence final demand. The most common form of classic integration is represented by creation of various transnational holdings. The driving power of a holding formation consists in striving to keep stable links and to improve own stability in economy by means of forming a balanced business portfolio. There are various kinds of corporate management within the framework of holding structures. Common objective advantages inherent with all the types of holdings are as follows:

- Substantial decrease in transaction expenditures;

- Scale effect;

- Substantial manufacturing synergy and risks hedging.

Since formation of cross-border cluster is an inherent evolution of social, technical and technological relations at the meso-level the cluster policy becomes a new policy in euroregional development [10]. A cross-border cluster as an economic agglomeration of mutually dependent business entity is a "growth point" or an important factor of steady social and economic development for euroregions. In this view, the cluster policy, firstly, creates favorable conditions to activate innovations in real sector of economy and for its modernization for further technological breakthrough. Secondly, such policy in poor resources environment and not always consistent national policy enables to solve social problems of a euroregion. With modern global economic trends and priorities social development becomes a prospective strategy to enable stability and competitiveness of peripheral territories. The part played by socially-oriented network clusters in euroregion becomes more important. M. Porter and M. Enright nominated, at least, three major reasons to stimulate development of cluster systems:

1) Increase labor efficiency and manufacturing efficiency;

2) Stimulate innovations;

3) Facilitate knowledge and production commercialization.

In the modern theoretical economics "integration - disintegration" dichotomy is complemented with one more category - "quasi-integration" and "corporation - market" dichotomy is extended with the "hybrid" category. Applying the clusters control criterion the quasi-integration may be defined as a process of establishing control of behavior of formally independent corporations with their property being beyond the control. There are various hybrid forms of cross-border quasiintegration as a grouping of euroregional business entities with stable long-term relations and assigned control of common activities without any legal transfer of proprietary titles: clusters, business associations, strategic alliances, various network groupings, etc. their common feature, as defined, is a greater share of medium and minor business, but not large business. 
Quasi-integration structures are network structures to which industrial and innovations clusters may be assigned to full extent. In other words, industrial and innovations clusters are quasi-integrated structures consisting of legally independent corporations where, with uncontrolled assets ownership titles there is a control of their management.

Review of quasi-integration processes within the CIS economic area might be carried on most obviously basin on concept of sub-regional integration with a region as a quasi-corporation, i.e. a substantial subject of economic activity producing public and private cross-border benefits, cooperating with corporations and governments and, thus, being one of subjects of economic power. However, in the author's opinion, cross-border integration is a complex process generating complicated systems. Therefore the cross-border euroregion contains multiple political and economic functions [11].

In the author's opinion, it is corporative integration which plays a key part in a process of possible international clusters formation as a meso-level of integration within the European economic space.

Science, high technologies and cross-border network organization structure transform geoeconomic space changing relations in manufacturing, influencing relations between cities and regions, "center - periphery" model. Advancing differentiation of local structures in network economy transforms global infrastructure of geo-economic system in total.

Thus, from the point of view of cross-border cooperation within the framework of international integration structures the most important criterion of its efficiency, in the author's opinion, lies in the transfer to unified trans-border region by means of border contact function development as a network cooperation.

Basing on researches it may be feasible to formulate certain specifics of a cluster model of crossborder cooperation as the most adequate in view of modern global economy development tendencies and stage of integration, in particular, within the framework of EU common economic space.

Cross-border business association (being either industrial or territorial union) is a form of horizontal integration. Its distinguishing feature consists in cooperation of competitors and partners from adjacent links of cost generation chain who provide their resources to develop and regulate common market, lobbying common interests in public entities, such form of integration becomes a key instrument to improve efficiency of industrial policy and enables sometimes to compensate both market failures and even national failures. Value of industrial communities lies in significant club advantages for their members (common brand or trademark, belonging to circle of chosen ones, lower costs of training, interests protection, information support, etc.). The most significant industrial benefit provided by the business association lies in interests lobbying at a lower cost, broad publicity and higher chance of positive solution. Specific feature of a cross-border cluster as a quasi-integration form lies in its geographical localization, preventing concentration of mutually dependent corporations, specialized suppliers and servicing organization within restricted territory, which compete and at the same time carry on common activities at both sides from national borders. Researching competitiveness problems M. Porter identified three major advantages of the clusters. Firstly, the clusters improve productivity providing the access to specialized resources and labor, facilitating access to information, institutions, social benefits. Secondly, the clusters motivate higher temps of generation of newer business entities transforming former employees of existing enterprise into new businessmen.

Thirdly, they increase opportunities for corporations to implement innovations by means of quicker diffusion of technological knowledge. Unique capability of cross-border clusters to speed up innovations diffusion permits to classify them as innovatively active economic formation or crossborder area of higher innovative activeness. Here the cluster positioning as a specific structural component of economy is complemented by its definition as a specific local social and cultural community with internal environment of trust and cooperation. The $\mathrm{CBC}$ facilitates the deepening 
of economic integrations of its members into global economy and increasing level of their international competitiveness due to formation of common manufacturing and sales chain, crossborder spreading of knowledge and innovation, costs saving achievement in manufacturing, reducing transaction expenditures due to common management bodies and reducing transport costs due to using common infrastructure, etc.

Cross-border cluster is an innovation model providing multiplicative effect in solving a complex of social, economic, scientific, technical, educational, political, investment problems of peripheral areas of Ukraine.

The cross-border cluster system is a newer type of a system with a newer ideologically functional configuration enabling to expand sphere of functional and organization relations which generate complex activity connecting people, aids, resources and newer paradigms for Ukrainian information space formation, monitor logistic chain of integrated application of all the interrelated types of resources.

It may be stated that a newer wave is generated in development of cluster theory. It confirms the significance of this topic and permits to develop this concept in the cross-border cluster systems.

Probable directions of the "second wave" in innovation clusters researches are enlisted below:

- clusters development in context of theory of evolutionary economics, cluster concept as business and ecological systems;

- possibilities and regulations of international cluster systems formation, including cross-border clusters;

- clusters as stimulating systems of internal and international economic progress;

- mutual competition and other synergies within the cluster and among clusters;

- reducing influence of territorial component of clusters' development, cooperation networks virtualization within the framework of "network space".

Important preconditions enabling to form objects of cross-border cluster systems are represented by strengthening of external and internal competition and necessity to involve euroregional enterprises into international chains generating added value. Essential factors facilitating clusters generation include activation of international cooperation between regions adjacent to national borders and implementation of large-scale joint projects of creating objects of transport, power-generating, touristic and leisure infrastructure.

Prospective industrial vectors of clusters development are visible in power-generation, transport and logistics, foreign trade, tourism and leisure complexes. Prospective sphere may include also scientific and technical cooperation between scientific and educational centers, which create favorable conditions for creation of cross-border innovations and implementation clusters.

Distinguishing feature of a cluster as a quasi-integration form is its geographical localization which is expressed in concentration mutually connected corporations, specialized suppliers and servicing structures within a restricted territory which compete with each other and carry on common activities at the same time. Clusters continue to remain such a theoretical construction which has not clear outline and positive external features. However, in a long-term future these quasi-integration forms will become a main driving force for innovative development. Essential significance from the point of view of treating clusters as a meso-level of international integration schemes is represented by modern tendency of changing territorial paradigm of global economy for spacious paradigm both at theoretical and practical levels and - as a consequence - a tendency to reduce gradually role of territorial component of industrial and innovative clusters and development of information virtual clusters and clouds of intra-cluster's and inter-clusters' relations. 
At the same time cluster concept is not dispersed as well, as it is not brought to an absolute. It is gradual reconsideration of the cluster definition as an eclectic concept within multiplicity of business entities and types of solution being selected that is taking place at the current moment.

In view of described actual trends an insistent demand is rising to reveal and analyze externalities of international integration groupings and formations and cluster systems as "overflow" effects. Their merging forms a field of effects produced by international cluster systems as a meso-level of international economic integration [10]. Basing on the analysis of international aspects in cluster development an international cluster system term has been introduced with its essential types outlined as international, cross-border and globalizing providing opportunities for development of said types of cooperation involving Ukrainian business structures.

The cluster concept itself experiences, in the author's opinion, the "second wave" of scientific and practical interest expressed in research of opportunities for internationalization of industrial and innovations clusters, understanding clusters in the evolutionary economy context as business and ecological systems bringing necessary variety and capability to adapt to existing model of network cooperation and possibilities to reveal both positive and negative externalities.

Like cross-border region, cross-border market is viewed upon as single, whole, poly-structural formation. Its main specific nature is the border and the necessity to coordinate the activity of certain border territories. It is realized by means of cross-border cooperation in different organization forms [11].

The institutions of cross-border market combine the system of formalized rules and non-formalized relations of the participants with the external environment. Synergetic effect which appears as a result of cooperation of cross-border market subjects is explained by cost saving, property right specification, transaction cost saving (according to R. Coase).

Cross-border industrial cooperation is viewed upon as the instrument of competitive recovery of periphery territories in terms of progressive technological development and the emergence of dominant technology of a new technological mode. The competitiveness of regions is the necessary condition of joining the global market and global exchange system, and cross-border regions are intensively developed in terms of globalization. Characterizing modern tendencies of production process change, M. Castells underlined that networks present the fundamental material out of which new organizations would be built. One of possible forms of network organization structures, which firmly occupied the place in modern economic theory and practice, are the clusters. According to M. Porter, "cluster is a network form which occurs in the range of geographical location where closeness of firms and institutions guarantees some forms of community and increases frequency and influence of cooperation".

The main task of cross-border clusterization is to enhance the competitiveness of crossborder region economy. It will not only give odds to the participants of business in terms of productiveness growth, transaction cost saving, wide access to market outlets, technologies, economy of scale and getting a synergetic effect, but it also contributes to the strengthening of competitive status of the European region, promotion of business activity, enhancing of investment prospects, facilitating of the most rational use of the resources, improvement of innovation environment, growth of export potential and providing steady development of social processes. According to M. Porter, geographical clusterization is one of the most dynamic and quickly spread processes of modern economic development. The experts of Economic Cooperation and Development Organization state that innovation clusters are "engines of economic growth of national economies and the realization of clusters initiatives is the key instrument of making countries competitive". The given thesis is confirmed by statistics which shows the role of clusters in economic development of some countries. At the beginning of 1980-s cluster concept became of practical importance - it transformed into the key element 
of economic and innovation policy of the leading countries of the world and cluster initiatives got the status of effective instruments of competitive growth of single regions and national economies as well.

In spite of the popularity of cluster subject, two key aspects still remain controversial - what crossborder cluster is and how to develop it.

The problem becomes complicated because independent subjects of economic activity of postmodernity resist directed centralized management and the clusters can be formed only from below. Incredible as it may seem, but network clusters cannot be formed in the truest sense of the word. In all importance of external stimulation of clusterization process, for example, in the form of national policy, the key place in each cluster taken by its history, by the trajectory of the previous development, is inseparable from the local institutional environment of the region and the special aspects of the certain object. Investigation of the cluster as an object showed that together with the clusters there exist a great majority of similar theories, in relation to which clusters, as usual, serve as unifying theory. It is our understanding that cross-border network cluster is a dynamic self-organized system generating innovations in the form of knowledge, new technologies and products under sufficient effectiveness of its participants at the expense of their synergy and group action.

It can be said that cross-border network clusters are geographic concentrations of inter-related enterprises (suppliers) of one or more innovation branches (including venture companies, universities, research and commissioning organizations, marketing and information agencies) and cooperating institutions that function on both sides of the border of the counties which compete, but at the same time cooperate with each other, gaining the benefit from specific local assets, joint cross-border location and embeddedness into economic and social area of the European region.

From the network theory point of view, clusters can be characterized as network of inter-related companies (including specialized suppliers) connected with each other into the chain of added value creation and the spread of new knowledge, products and technologies on the territory of the European region, which mutually contribute to the growth of innovation competitiveness of periphery regions by means of greater transparency of new technologies, risks distribution and transport cost saving.

Network cluster is a self-organizing system in economics one of the main important order parameter of which is the structure being inter-related with the institutional environment.

Cross-border clusters were created in Europe together with the European regions formation. Many of them work without coordination structures or use the services of regional development agencies being at the same time participants of the European regions. The European regions can be used as coordination structures of those cross-border clusters the participants of which are the economic management subjects of Ukrainian border regions. At the same time the cooperation in the sphere of culture is spread on the education and science, tourist and recreation activity which resulted in the increase of border habitants' activity, their participation in social organizations, etc. The activation of cooperation and its promotion on the part of European Union resulted in theories of mutual development of the European regions which in their turn helped to work out the strategies of mutual development of cross-border regions and the mechanisms of their realization.

Detailed analysis of social and economic development of cross-border region which was herein made, allowed to work out more significant cross-border projects, for example, creation of joint production areas or formation of cross-border clusters. Thus, the necessity of creating of competitive economic system in cross-border region stimulated the search of decision from the perspective of possibilities of mutual usage of existing and creation of new capacities and also the development of production and technical cooperation (agricultural, industrial enterprises, service organizations, innovation and investment activity). 
Cross-border cluster systems embrace adjoining border territories of neighboring countries which include groups of independent companies and associated institutions, geographically located in cross-border region. The peculiarity of cross-border clusters is the necessity of taking into account by the participants of cross-border institutions different tax, customs and legislative environment of neighboring countries in their activity. Clusters, using local natural and resource, social and economic, infrastructural potential, geographical and economic location of the territories of cross-border countries enhance the competitiveness of the regions, provide adequate standard of living of the inhabitants. Within them there are created the conditions to form and develop technical parks, logistic centers, techno-policies and other innovation forms of economic activity organization.

The main tasks of formation and support of the cross-border development are:

1) competitive recovery of cross-border regions, enhancing of human life index;

2) promotion of new and development of existing European regions as institutional platform to reveal cross-border cluster initiatives and development of cross-border clusters;

3) providing of innovation and investment model of development of enterprises and other subjects of economic activity located in cross-border regions, implementation of new technologies in the production of goods and services.

Cluster advantages are fully realized only due to such modern managing technologies as subcontracting and outsourcing - "falling externally", based on the emphasizing of key cooperation positions and focusing all economic ties on them. The process of subcontracting provides the existence of the main enterprise - "contractor" and a great majority of small and middle enterprises "subcontracting". Contractor or subcontractor makes an agreement according to which the contractor entrusts one or more enterprises (subcontractors) to produce details, components or key parts necessary to produce the final product. Outsourcing provides the cooperation under which "external" company which sells its goods and services to the customer is included into "managing outlines" of the customer as functional element in which case being legally and managerial independent.

Cluster approach naturally combines interests of business and territory as under this form of economy organization it is possible to mutually intensify their competitiveness. Cluster approach is directly connected with competitiveness recovery of the territory not only because it simultaneously influences the competitiveness basis (efficiency and employment), but also because it removes the contradiction between them. The level of labor productiveness in a cluster grows due to the specialization and outsourcing of incidental activities, the level of employment - due to the participation and formation of new subjects of economic activity in related and supporting branches.

Network clusters formation results in efficient competitive recovery of the European regions' economy due to several factors.

Firstly, it is the reducing of transaction expenses at the expense of more efficient realization of long-term contract between industrial organizations, financial credit institutions, trade organizations, scientific and innovation organizations; fulfillment centralization of a range of general functions of companies-participants of a cluster; implementation of general cluster of informational and analytical system that promotes information exchange between the participants either vertically or horizontally.

Secondly, it is the possibility to provide competitive advantages at the expense of better quality and price of the goods selling; innovation potential, sufficiency of production and merchandising power; existence of long-term strategy of activity; optimization of external and internal cluster connections.

Thirdly, it is the possibility to use the potential of mutually beneficial long-term business relations; to develop the system of mutual deliveries within a cluster, built on the principles of trust; to form 
general sales network; to carry out intensive exchange of information, financial, human, innovation resources; to reduce the functioning risks at the expense of level of profitability reducing of the enterprises participating in a cluster; to follow the priorities of external cluster planning and the aims and tasks being set; to develop the system of cross-shareholdings within a cluster.

Fourthly, it is a profit based upon the theory of production and financial management which includes:

- Economy at the expense of economy of scale;

- Efficient use of natural resources potential of the region;

- Diversification that provides the risks cushioning;

- Synergetic effect.

In the process of transaction to post-industrial development the function of cross-border area as the development environment will be enhanced so much that it could become a new important siting of productive forces. Autonomy of cross-border economic environment as siting and production factor proves the possibility of synergetic effect formation, added value formation at the expenses of business entity interaction which is an essential element of economic area.

In the process of European integrity the border regions reconstruct their economic area: from semicircular determined by precedence of barrier function of the border up to circular determined by weakening or disappearing of this function. Respectively, during the European integrity processes the border regions cease to bear the name "periphery" on the national level, becoming full players (agents) of the united European economic area.

\section{Conclusions}

In the economic area of postmodernity the main objects of efficient economic board become industrial business networks which under the influence of globalization and internationalization processes obtain the form of "hybrid" institutions of horizontal integration - network clusters which are the agents of technological changes as they unite the scientific research organizations and their commercialization and manufacturing application.

The cluster approach becomes the most efficient instrument for development of international economic cooperation under modern conditions and, finally, construes a meso-level of competitive international integration systems and essential precondition for quality integration advance in European economic area. Modern tendency to change territorial global economy paradigm for spacious with consequent tendency to reduce gradually territorial component of industrial and innovation clusters and development of information virtual clusters in euroregions involving Ukraine gains an important role from the point of view of considering cross-border clusters as a meso-level of international integration systems.

Thus, necessity of formation and identification essential meso-level particulars for international integrating groupings being organization or administrative structures of intra-industrial or interindustrial cooperation in the form of cross-border cluster systems combining macro- and microlevels of national economy integration is proved. Newer postmodern reality lies in combination of post industrial manufacturing with network economic space providing for institutions transplantation by means of self-organization of hybrid network clusters at both sides of a national border, which becomes a factor facilitating concentration and free circulation of capital funding in euroregions. In modern post-industrial paradigm of euroregional development priority of essential factors of deployment sustained substantial transformations changing the function of peripheral territories from physical basis as a location of deployment of material factors it is more and more shifting to specious environment for development of labor resources, innovations and selfdevelopment promotion. 
On its way to join European Union, Ukraine has to sum up the experience of cross-border cooperation being a preliminary and supplying stage of integration in the regions: to form integral and efficient policy of cross-border cooperation development in Ukraine it is necessary to work out the theory and methods of cooperation basis and to justify new forms and mechanisms of its extension in the light of cross-border network clusters concept; nowadays it is of immediate interest to work out and implement cross-border strategy of European regions development taking into account European experience of cross-regional strategies, the object of which is the steady social and economic development of European regional system as read in conjunction with its human, natural, resource and industrial potential and institution environment.

Thus, investigation and analysis of worldwide progressive experience in formation and development of cross-border clusters will make it possible to successfully realize the tasks of Strategy for Innovation Development of Ukraine for 2010-2020 under the conditions of grand challenges, secure funds in the modernization of industry, to develop the national innovation system. The creation of cross-border innovation clusters system which provides for intensive exchange of resources, technologies and know-how is achieved by strengthening of competitive positions of home companies at European market and by the growth of innovation potential of Ukrainian economy in the process of European Union extension.

\section{References}

1. Declaration concerning regionalism in Europe (1996). Assembly of European Regions, Secretariat General Immeuble Europe, Strasbourg, 10 .

2. Cluster policy in Europe (2008). A brief summary of cluster policies in 31 European countries, Europe Innovation Cluster Mapping Project, Oxford Research AS, 34 p.

3. Williamson, O. (1985). The economic institutions of capitalism, Free Press, New York, $450 \mathrm{p}$.

4. Coase, R. G. (1994). Nature of the firm, Lessons business organization, Lenizdat, St. Petersburg, p. 29 [in Russian]

5. Marshall, A. (1928). Elements of economics of industry being the first volume of elements of economics, London, $460 \mathrm{p}$.

6. Porter, M. E. (1998). Clusters and competition: new agendas for companies, governments, and institutions, Harvard Business School Working Paper, Boston, MA, No. 98-080.

7. Porter, M. E. (1990). The competitiveness advantage of nations, Macmillan, London.

8. Armstrong, H. W. (1995). The role and evolution of European Community Regional Policy. B. Jones, M. Keating (Eds.). The European Union and the Regions, Clarindon press, Oxford, pp. 23-62.

9. Rekord, S. I. (2012). Methodology of the cluster systems development as a mesolevel of international economic integration [Metodologiya razvitiya klasternykh sistem kak mezourovnya mezhdunarodnoy ekonomicheskoy integratsii], Izd-vo SPbGUEF, Sankt-Peterburg, 211 s. [in Russian]

10. Rekord, S. I. (2010). The industrial-innovative clusters development in Europe: evolution and contemporary discussion [Razvitie promyshlenno-innovacionnyh klasterov $v$ Evrope: evolyuciya i sovremennaya diskussiya], Izd-vo SPbGUEF, Sankt-Peterburg, 109 s. [in Russian]

11. Anderson, N. V. (2007). Ukraine-EU trans-border cooperation: developing Euroregions on the border (the case study of lower danube). In: Democracy vs. Authoritarianism, Abstracts, Warsaw East European Conference, Warsaw, pp. 11-12. 